University of Nebraska - Lincoln

DigitalCommons@University of Nebraska - Lincoln

Mammalogy Papers: University of Nebraska

State Museum

Museum, University of Nebraska State

$1-14-1985$

\title{
Tracking Mammals with Fluorescent Pigments: A New Technique
}

Cliff A. Lemen

University of Nebraska-Lincoln, clemen2@unl.edu

Patricia W. Freeman

University of Nebraska-Lincoln, pfreeman1@unl.edu

Follow this and additional works at: https://digitalcommons.unl.edu/museummammalogy

Part of the Zoology Commons

Lemen, Cliff A. and Freeman, Patricia W., "Tracking Mammals with Fluorescent Pigments: A New Technique" (1985). Mammalogy Papers: University of Nebraska State Museum. 15.

https://digitalcommons.unl.edu/museummammalogy/15

This Article is brought to you for free and open access by the Museum, University of Nebraska State at DigitalCommons@University of Nebraska - Lincoln. It has been accepted for inclusion in Mammalogy Papers: University of Nebraska State Museum by an authorized administrator of DigitalCommons@University of Nebraska Lincoln. 
TRACKING MAMMALS WITH FLUORESCENT PIGMENTS: A NEW TECHNIQUE

\author{
Cliff A. Lemen and Patricia W. Freeman
}

School of Biological Sciences, University of Nebraska, Lincoln, NE 68588-0118 University of Nebraska State Museum, University of Nebraska, Lincoln, NE 68588-0514

Extensive study of nocturnal rodents by mammalian ecologists who wish to quantify patterns of movement such as habitat preference or size and shape of home range is difficult at best. The primary problem faced in these attempts is that the mammals in question are secretive, small, nocturnal and, as a consequence, nearly impossible to watch. Unlike more easily observed animals such as birds or diurnal mammals, much of what we know about movements of nocturnal rodents must come indirectly from trapping. By its nature, however, trapping can only yield fairly coarse information on movement patterns, and little is known as to how baited traps may affect the behavior of the animals. More recently, some ecologists have turned to the use of radio transmitters. Radio tracking has many advantages over trapping, but it is expensive and can typically only locate the rodent within a few meters (Schroder, 1979; Banks et al., 1975). Infrared scopes, starlight scopes, and infrared video (Connors and Masters, 1978) can be effective in tracking large nocturnal animals or small ones confined in a cage, but the use of such devices to observe small nocturnal mammals is extremely difficult in field situations. Another approach is to use low levels of artificial light to observe 
animals at night (Thompson, 1982). However, it is not known how artificial lights affect animals, and observations can only be made within the confines of the lighted area.

We have developed a new technique for following the movement of small mammals at night. It entails the use of fluorescent pigments and ultraviolet light. This method allows one to gather extremely accurate information on the location of animals and to trace the movement of individuals for up to $900 \mathrm{~m}$. For much of this distance a detailed record is left by the trail of pigment. It can then be determined which objects are manipulated, what plants are climbed, what burrows are entered and which items are eaten. The use of fluorescent pigments to track animals has two other major advantages. First, it is inexpensive; all that is needed are the pigments and a UV light source (Appendix). Second, the pigments are reported by its manufacturer to have low toxicity (they have been used in food habit studies), and we have found that animals can be exposed repeatedly to the pigments without apparent ill effects. This new method will allow quick and accurate determination of the macro- and microhabitat use by small mammals. Detailed information on home range, movement patterns, and habitat use can be found within a matter of a few days.

Pigments used in this study can be obtained in several colors, but the colors that are easiest to detect and distinguish are red, orange, and green. We are now experimenting with mixing the colors. These mixtures are different from the three basic colors, but they are often difficult to distinguish from one another in field situations. In those studies where more colors are needed, we have found that the grains of the original colors are readily distinguished under $100 \times$ magnification. Having to use such magnification to definitely identify trails will be laborious, but it does open the possibility of 12 or more unique marker colors. The ultraviolet light source we use produces longwave UV light and is therefore relatively safe to use for prolonged periods.

The method for marking animals is to set traps at sunset and check them about $3 \mathrm{~h}$ later. Animals trapped are put into a plastic bag with the pigment, gently shaken, and released. The fur of the animal will have been saturated with the fine dust of the pigment. The next night we return to this trap station with an ultraviolet lamp and follow the fluorescent trail of pigment left by the rodent as it brushed against the vegetation. We have found that the pigment is still detectable on the animal the second night, but the animal no longer leaves a trail. The trails persist until a heavy rain.

We have used this method with a rodent community in the sandhills of central Nebraska. For habitat analysis we place a marker flag every $3 \mathrm{~m}$ along the trails. The positions of the flags can be mapped using surveying equipment such as a plane table and alidade. For more detailed analysis of the paths, markers were put closer together along the trail, in our case every $10 \mathrm{~cm}$. The path is then quantified by finding the angle of turn every $10 \mathrm{~cm}$. This information is used to create a detailed map of the movement of an individual.

Because the information obtained with this method is so accurate, it is possible to trace animals to their burrows and note exactly which plants they had fed upon. Another feature of the method is the ability to quantify the vertical as well as horizontal use of the habitat. For example, we found that Perognathus flavescens routinely climbs stalks of Carex sp. (sedge) to get at the fruiting heads, whereas $P$. hispidus repeatedly climbs into the tops of Helianthus petiolaris (an annual sunflower) for the same reason. To our surprise even the highly bipedal Dipodomys ordii can climb a meter into a Helianthus and cut off a flowering head. It then goes back to the ground and consumes it. The vertical component of a rodent's habitat use in a grassland is limited, but our method also works well in brushlands and forests with small trees. A limited amount of data collected on Peromyscus truei in New Mexico, for example, indicates that their movements can be followed in piñon-juniper forests of the southwest. The main limitation of our new method is that poor trails are left by rodents if there is no grass or forb cover on the ground.

We wish to thank John Janovy and the Cedar Point Biological Station for their support of this project in Nebraska and thanks to Richard Smartt for his aid on the work done in New Mexico. Special thanks to Kelly Wehrman and Terry Kroll for pointing out to us the existence and potential of these fluorescent pigments. This research was supported in part by a Fling Fellowship from the University of Nebraska Foundation.

\section{Literature Cited}

BANKs, E. M., R. J. BRoOKs, AND J. SCHNELL. 1975 A radiotracking study of home range and activity of the brown lemming (Lemmus trimucronatus). J. Mamm., 56:888-901.

Connors, W. E., and W. M. Masters. 1978. Infrared video viewing. Science, 199:1004.
SCHRODER, G. D. 1979. Foraging behavior and home range utilization of the bannertail kangaroo rat (Dipodomys spectabilis). Ecology, 60:657-665.

Tномpson, S. D. 1982 . Microhabitat utilization and foraging behavior of bipedal and quadrapedal heteromyid rodents. Ecology, 63:1303-1312. 
Submitted 11 April 1984. Accepted 14 June 1984.

\section{APPENDIX}

The pigment we used was obtained from Radiant Color, 2800 Radiant Rd., Richmond, CA 94804. Prices averaged about 5-6 dollars per pound can of pigment. A pound can of pigment would be enough to mark well over 100 small mammals. Any longwave UV light source will work to illuminate the pigment; we use a Blakray lamp, ML-49, from Ultra-Violet Products Inc., San Gabriel, CA 91778. However, less expensive versions can be made from common fluorescent tube laterns and a longwave UV tube (Sylvania F8T5/ BLB).

also Fisher Scientific

Pigment R-103 series green (chartreuse) red-orange orange-yellow 